\title{
EVALUASI KESESUAIAN LAHAN TANAMAN CABAI PIPER RETROFRACTERUM di KECAMATAN KAMANG MAGEK KABUPATEN AGAM
}

\author{
Ahmad Fikrizal \\ *Mahasiswa S1 Prodi Geografi**Dosen Jurusan Geografi Universitas Negeri Padang \\ Email : ahmadfikrizal17@gmail.com
}

\begin{abstract}
Abstrak
Penelitian ini dilakukan pada Kecamatan Kamang Magek, Kabupaten Agam, pada bulan desember 2016 bertujuan untuk mendapatkan data dan informasi mengenai (1) Karakteristik lahan berkaitan dengan syarat tumbuh tanaman cabai (2) Kesesuaian lahan area tanaman cabai pada daerah penelitian. Penelitian yang dilakukan termasuk jenis penelitian deskriptif, sampel diambil dari peta satuan bentuklahan yang diperoleh dari hasil overlay peta bentuklahan dengan peta lereng, peta jenis tanah, peta geologi, peta penggunaan lahan. Teknik analisis data yang digunakan untuk mengetahui karakteristik lahan dan kesesuaian lahan adalah Metode matching atau pencocokan setiap karakteristik lahan. Hasil penelitian menunjukkan (1) Tingkat kesesuaian lahan terdiri dari tingkat sesuai (S2) sebanyak tiga satuan lahan. Cukup sesuai (S3)sebanyak empat satuan lahan dan tidak sesuai sebanyak 5 satuan lahan (N) (2) Karakteristik kesesuaian lahan pada daerah penelitian memiliki lereng yang beragam dari datar(0-8\%), landai (8-14\%), curam (25-40\%), sangat curam $(>40 \%)$, liat. pH tanah berkisar antara 5,05-6,75. Permeabilitas antara 2,91-poros (tak terhingga). Curah hujan 1898,5 mm/thn. Bulan kering berjumlah 8 dan suhu $21^{0} \mathrm{C}$.Terdiri dari hutan yang memiliki luas $3707,51 \mathrm{Ha}$, kebun campuran memiliki luas 511,67 Ha, tegalan memiliki luas 624,48 Ha, semak belukar memiliki luas 1877,44 Ha, sawah memiliki luas 1877,44 Ha dan permukiman memiliki luas sebanyak 369,54 Ha.
\end{abstract}

Kata Kunci: bentuklahan dan satuan bentuklahan, kesesuaian lahan, karakteristik lahan, kecamatan Kamang Magek.

\begin{abstract}
This research was conducted on Kamang Magek Subdistrict, Regency of Agam, in December 2016 aimed to get data and information about (1) Characteristic of land related to the requirement of growth of chilli plant (2) Land suitability of chilli area area in research area. The research includes descriptive research type, the sample is taken from the map of the unit of land form obtained from the overlay of landform map with slope map, soil type map, geological map, land use map. Data analysis techniques used to determine land characteristics and land suitability is the method of matching or matching each land characteristic. The results showed (1) The level of land suitability consisted of the corresponding level (S2) of three units of land. (2) Land suitability characteristics in the study area have varying slopes from flat (0-8\%), ramps (8-14\%), steep slopes (8-14\%), steep slopes (25-40\%), very steep (> 40\%)., Clay. Soil pH ranges from 5.05 to 6.75. Permeability between 2.91-axis (infinity). Rainfall 1898,5 mm / yr. The dry season is 8 and the temperature is $210 \mathrm{C}$. It consists of 3707.51 ha of forest, mixed plantation with an area of 511.67 ha, the moor has an area of $624.48 \mathrm{ha}$, the bush has an area of $1877.44 \mathrm{ha}$, the rice field has an area of 1877, $44 \mathrm{Ha}$ and the settlement has an area of $369.54 \mathrm{Ha}$.
\end{abstract}

.Keywords: landforms and landform units, land suitability, land characteristics, Kamang Magek district.

Artikel ini ditulis dari skripsi penulis dengan judul Evaluasi Kesesuaian Lahan Tanaman Cabai Piper Retrofracterum di Kecamatan Kamang Magek Kabupaten Agam untuk periode Maret 2018 


\section{A PENDAhuluan}

Indonesia dikenal dengan berbagai kekayaan sumber daya alamnya, baik yang terdapat di wilayah daratan seperti kekayaan hutan, lahan-lahan pertanian yang subur, kekayaan barang tambang, serta berbagai keanekaragamaan flora dan fauna maupun sumber daya alam yang terdapat di wilayah perairan seperti kekayaan laut. Sumber daya alam ini sangat berperan penting bagi kehidupan masyarakat Indonesia dalam rangka memenuhi kebutuhan manusia dan juga untuk meningkatkan devisa negara Indonesia.

Sumber daya alam ini sangat perlu sekali untuk di kembangkan salah satunya sumber daya lahan. Potensi yang dimiliki oleh sumber daya lahan pada tiap-tiap daerah berbeda-beda. Sumber daya lahan ini memiliki tingkat penghasilan produktivitas tanaman pangan yang berbeda-beda pula pada tiap-tiap daerah. Perbedaan tersebut tergantung kepada lingkungan fisik maupun lingkungan manusia, oleh sebab itu manusia harus dapat mengetahui informasi untuk menentukan penggunaan lahan, beserta informasi tentang lahan sangat diperlukan dalam pemanfaatan lahan.

Lahan mempunyai pengertian suatu lingkungan fisik yang meliputi tanah, iklim, relief, hidrologi dan vegetasi, dimana faktor-faktor tersebut mempengaruhi potensi penggunaannya. Termasuk

didalamnya adalah akibat-akibat kegiatan manusia, baik pada masa lalu maupun sekarang, seperti reklamasi daerah-daerah pantai, penebangan hutan dan akibat-akibat yang merugikan seperti erosi dan akumulasi garam (FAO 1976 dalam Sarwono Hardjowigeno dan Widiatmaka 2011). Lahan merupakan sebagai suatu ruang ditemukan bumi yang secara alamiah dibatasi sifatsifat fisik serta bentuk lahan tertentu. \begin{tabular}{lrr}
\multicolumn{2}{c}{ Tanaman cabai adalah } \\
tumbuhan perdu & berkayu, dan \\
buahnya berasa pedas yang \\
disebabkan oleh
\end{tabular} kapsaisin. Indonesia tanaman tersebut dibudidayakan sebagai tanaman semusim pada lahan bekas sawah dan lahan kering atau tegalan namun demikian syarat-syarat tumbuh tanaman cabai harus dipenuhi agar dapat diperoleh pertumbuhan tanaman yang baik dan hasil buah yang tinggi. Saat ini luas lahan panen tanaman cabai di Indonesia adalah 128.734 Ha dengan hasil produksi sebesar 1.074.602 ton per tahun. Sentra produksi tanaman cabai di Indonesia adalah Pulau Jawa dengan total produksi sebesar 556.669 ton atau sekitar 51,80 persen dari total produksi cabai nasional. Adapun provinsi penghasil cabai terbesar adalah Jawa Barat dengan produksi 253.296 ton atau sebesar 23,57 persen dari total produksi cabai nasional, diikuti oleh Jawa Tengah dan Jawa Timur. Sedangkan provinsi penghasil 
cabai terbesar di luar Jawa adalah Sumatera Utara dengan produksi sebesar 147.810 ton dan diikuti oleh Sumatera Barat (Statistik Produksi Holtikultura Kementerian Pertanian Direktorat Jenderal Holtikultura 2015)

Tanaman cabai dapat tumbuh pada berbagai jenis tanah, asal drainase serta aerasi tanah cukup baik, air cukup tersedia selama pertumbuhan dan perkembangan tanaman. Tanah yang ideal untuk penanaman cabai adalah tanah yang gembur, remah, mengandung cukup bahan organik (sekurang-kurangnya $1,5 \%)$, unsur hara dan air, serta bebas dari gulma. Tingkat kemasaman $(\mathrm{pH})$ tanah yang sesuai adalah 6-7. Kelembaban tanah dalam keadaan kapasitas lapang (lembab tetapi tidak becek) dan temperatur tanah antara 24-30 $\mathrm{C}$ sangat mendukung pertumbuhan tanaman cabai. Temperatur tanah yang rendah akan menghambat pengambilan unsur hara oleh akar, walaupun cabai dapat ditanam hampir di semua jenis tanah dan tipe iklim yang berbeda, tetapi penanaman yang luas banyak dijumpai pada jenis tanah mediteran dan aluvial tipe iklim D3/E3 (0-5 bulan basah dan 4-6 bulan kering) (Nani Sumarni dan Agus Muharam tahun 2005).

Propinsi Sumatera Barat sebagai salah satu penghasil cabai di Indonesia sangat diperhitungkan dalam hasil produksi cabainya, luas lahan tanaman cabai yang dimiliki oleh Sumbar sampai pada tahun 2013 adalah seluas $75.542 \mathrm{Ha}$ dengan hasil produksinya adalah 95.663 ton (Badan Pusat Statistik Sumatera Barat dalam Angka 2013). Salah satu penghasil cabai di Sumatera Barat adalah Kabupaten Agam yang mempunyai areal penanaman cabai seluas 1.161 ha dengan hasil produksi 9.580 ton sampai tahun 2013 (Survei pertanian, Kabupaten Agam dalam angka 2013). Kecamatan Kamang Magek adalah salah satu penghasil tanaman cabai di Kabupaten Agam. Kecamatan Kamang Magek merupakan kecamatan baru semenjak terjadi pemekaran pada bulan Desember 2001 dari Kecamatan Tilatang Kamang. Kecamatan Kamang Magek yang terletak antara

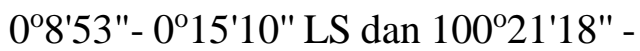
$100^{\circ} 27^{\prime} 40^{\prime \prime}$ BT, dan berada pada ketinggian rata-rata $850 \mathrm{~m}$ dpl dengan luas wilayah 99,60 km² (Kecamatan Kamang Magek dalam angka 2015) yang di jelaskan pada tabel 1 .

Tabel 1. Produksi Cabai di Kecamatan Kamang Magek

\begin{tabular}{|l|l|l|l|}
\hline No & Tahun & $\begin{array}{l}\text { Luas } \\
\text { lahan } \\
\text { (ha) }\end{array}$ & $\begin{array}{l}\text { Produksi } \\
\text { cabai(ton) }\end{array}$ \\
\hline 1 & 2010 & 45 & 250 \\
2 & 2011 & 42 & 198 \\
3 & 2012 & 38 & 196 \\
4 & 2013 & 40 & 193 \\
\hline & Jumlah & & 837 ton \\
\hline
\end{tabular}

Sumber: BPS. Kamang Magek dalam Angka 2013. 


\section{Kajian Teori}

Bentuklahan, Satuan bentuklahan, dan Satuan Lahan

Lahan merupakan bagian dari bentang alam yang mencakup pengertian lingkungan fisik, topografi dan keadaan vegetasi alami yang semuanya secara potensial berpengaruh terhadap penggunaan lahan. Lahan mempunyai pengertian suatu lingkungan fisik yang mencakupi iklim, relief tanah, hidrologi, dan tumbuhan yang sampai pada batas tertentu akan mempengaruhi kemampuan penggunaan lahan. Lahan diartikan sebagai lingkungan fisik yang terdiri atas iklim, relief, tanah, air dan vegetasi serta benda yang diatasnya sepanjang ada pengaruhnya terhadap penggunaan lahan termasuk didalamnya hasil kegiatan manusia dimasa lalu dan sekarang seperti hasil reklamasi laut, pembersihan vegetasi dan juga hasil yang merugikan seperti yang tersalinasi. Menurut Hermon lahan merupakan lingkungan fisik yang terdiri dari iklim, relief, tanah, air, vegetasi serta benda yang berda di atasnya sepanjang ada pengaruhnya terhadap penggunaan lahan. (Dedi Hermon dan Khairani 2009).

Satuan bentuklahan adalah kenampakan medan atau relief yang terbentuk oleh proses-proses alami sehingga dapat dikenal dalam batasbatas yang memberikan informasi tentang stuktur komposisi, kekerasan dan keseragaman. Satuan bentuklahan adalah bagian lahan yang mempunyai kualitas dan karakteristik tertentu sehingga dapat di tentukan batasnya pada peta (Dibyosaputro,1998). Menurut Verstappen 1985 dalam Dibyosaputro (1998) klasifikasi bentuklahan di klasifikasikan berdasarkan pada: genesis, proses, dan batuan. Terdapat 9 satuan bentuk lahan berdasarkan genesanya, yaitu : a) bentuklahan asal vulkanik (V), b) bentuklahan asal strukural (S), c) bentuklahan asal proses denudasional (D), d) bentuklahan asal proses fluvial $(\mathrm{F}), \mathrm{e})$ bentuklahan asal proses marin $(\mathrm{M}), \mathrm{f}$ ) bentuklahan asal proses angin (A), g) bentuklahan asal proses pelarutan $(\mathrm{P})$, h) bentuklahan asal glasial (G), i) bentuklahan asal aktivitas organisme (O).

a. Curah hujan

Tabel 2. Intensitas Curah Hujan

\begin{tabular}{|l|l|}
\hline $\begin{array}{l}\text { Tingkatan } \\
\text { hujan }\end{array}$ & Curah hujan \\
\hline $\begin{array}{l}\text { Sangat } \\
\text { lemah }\end{array}$ & $\begin{array}{l}<100 \\
\mathrm{~mm} / \text { tahun }\end{array}$ \\
\hline Lemah & $\begin{array}{l}100-300 \\
\mathrm{~mm} / \text { tahun }\end{array}$ \\
\hline Sedang & $\begin{array}{l}300-2500 \\
\mathrm{~mm} / \mathrm{tahun}\end{array}$ \\
\hline Deras & $\begin{array}{l}2500-3000 \\
\mathrm{~mm} / \mathrm{tahun}\end{array}$ \\
\hline $\begin{array}{l}\text { Sangat } \\
\text { deras }\end{array}$ & $\begin{array}{l}>3000 \\
\mathrm{~mm} / \mathrm{tahun}\end{array}$ \\
\hline
\end{tabular}

Sumber : Chay Asdak 1995

b. Suhu udara

Tabel 3. kelas suhu udara

\begin{tabular}{|l|l|}
\hline $\begin{array}{l}\text { Tingkatan } \\
\text { suhu }\end{array}$ & $\begin{array}{l}\text { Suhu } \\
\left({ }^{\circ} \mathrm{C}\right)\end{array}$ \\
\hline Sangat baik & $<35^{\circ} \mathrm{C}$ \\
\hline
\end{tabular}




\begin{tabular}{|l|l|}
\hline Tinggi & $\begin{array}{l}30- \\
35^{\circ} \mathrm{C}\end{array}$ \\
\hline Sedang & $\begin{array}{l}25- \\
30^{\circ} \mathrm{C}\end{array}$ \\
\hline Rendah & $\begin{array}{l}20- \\
25^{\circ} \mathrm{C}\end{array}$ \\
\hline $\begin{array}{l}\text { Sangat } \\
\text { rendah }\end{array}$ & $<20^{\circ} \mathrm{C}$ \\
\hline
\end{tabular}

Sumber:Sarwono Hardjowigeno dan Widiatmaka 2011.

\section{Kesesuaian lahan}

Menurut Ritung dkk (2007) kesesuaian lahan tersebut dapat dinilai untuk kondisi saat ini (kesesuaian lahan aktual) atau setelah diadakan perbaikan (kesesuaian lahan potensial). Kesesuaian lahan aktual adalah kesesuaian lahan berdasarkan data sifat biofisik tanah atau sumber daya lahan sebelum lahan tersebut diberikan masukan-masukan yang diperlukan untuk mengatasi kendala. Data biofisik itu berupa karakteristik tanah dan iklim yang berhubungan dengan syarat tumbuh tanaman yang dievaluasi. Kesesuaian lahan potensial menggambarkan kesesuaian lahan yang akan tercapai apabila dilakukan usaha-usaha perbaikan. Lahan yang dievaluasi dapat berupa hutan konversi, lahan terlantar tidak produktif atau lahan pertanian yang produktivitasnya kurang memuaskan tetapi masih memungkinkan untuk dapat ditingkatkan bila komoditasnya diganti dengan tanaman yang sesuai.

Menurut (FAO, 1976 dalam Ritung dkk 2007) menyatakan bahwa sistem klasifikasi kesesuaian lahan terdiri dari empat kategori yang menunjukan tingkatan generalisasi yang sifatnya menurun, yakni sebagai berikut ini: (1) Ordo kesesuaian lahan (order), menunjukkan jenis kesesuaian lahan atau keadaan kesesuaian secara umum. (2) Kelas kesesuaian lahan (class), menunjukan tingkat kesesuaian dalam ordo. (3) Sub-kelas kesesuaian lahan (subclass), menunjukkan jenis pembatas atau macam perbaikan yang diperlukan di dalam kelas (4) Satuan kesesuaian lahan (unit), menunjukkan perbedaan-perbedaan kecil yang diperlukan dalam pengelolaan didalam sub-kelas.

Penentuan jumlah kelas ini didasarkan pada keperluan minimum untuk mencapai tujuan interpretasi dan umumnya terdiri dari lima kelas sebagai berikut :

1) Kelas $S_{1}$ (sangat sesuai) lahan yang tidak mempunyai pembatas yang tidak berarti dan tidak berpengaruh secara nyata terhadap produksinya

2) Kelas $S_{2}$ (sesuai) lahan yang mempunyai batsan-batasan yang agak berat untuk penggunaan lahan yang lestari. Pembatas akan mengurangi produktivitas atau keuntungan dan perlu menaikan masukan yang diperlukan.

3) Kelas $S_{3}$ (cukup sesuai) lahan yang mempunyai pembatas-pembatas yang sangat berat untuk suatu penggunaan yang lestari. Pembatas akan mengurangi produktivitas atau keuntungan dan 
perlu menaikkan masukan yang diperlukan.

4) Kelas $\mathrm{S}_{4}$ (kurang sesuai) lahan yang mempunyai pembatas yang sangat berat, tetapi masih memungkinkan untuk diatasi, hanya tidak diperbaiki dengan tingkat pengetahuan sekarang ini dengan biaya yang rasional.

5) Kelas $\mathrm{S}_{5}$ (tidak sesuai) lahan yang mempunyai pembatas yang sangat berat sehingga tidak mungkin untuk digunakan bagi suatu penggunaan yang lestari.

Berdasarkan dari kualitas hasil produksi tanaman cabai yang di hasilkan pada Kecamatan Kamang Magek ini masih tegolong kurang baik yaitu di bawah kualitas yang baik yaitu berkisar 30-35\%. Kecamatan Kamang Magek ini baru memiliki kualitas produksi 20-27\% (BPS Kamang Magek dalam Angka 2013). Masih rendahnya kualitas produksi cabai di daerah ini mungkin disebabkan oleh minat warga sekitar yang kurang untuk menanam cabai karena tanaman cabai ini tanaman semusim dan mudah terjangkit hama penyakit, tanah yang kurang subur, pengelolaan yang kurang baik dan tepat atau lahan yang tidak cocok untuk tanaman cabai. Produktivitas tanaman cabai itu juga bila dilihat dengan luas areal yang telah ditanami tanaman cabai masih kecil jika dibandingkan dengan luas tanaman

Peta 1. Administrasi Kecamatan Kamang Magek. padi atau belum dimanfaatkan seoptimal mungkin untuk meningkatkan kualitas produksi tanaman cabai. Dugaan-dugaan tersebut memerlukan jawaban dengan pembuktian melalui suatu penelitian, apalagi di daerah ini belum ada penelitian yang menitikberatkan pada lahan, khususnya untuk tanaman cabai. Penelitian ini melihat dan meneliti lahan yang sesuai untuk pengembangan tanaman cabai dengan melibatkan karakteristik lahan berdasarkan syarat tumbuh tanaman cabai maka judul penelitian ini Evaluasi kesesuaian Lahan Tanaman cabai Piper retrofractrum di Kecamatan Kamang Magek Kabupaten Agam.

\section{B METODE PENELITIAN}

Jenis Penelitian

Metode yang digunakan dalam penelitian ini adalah penelitian deskriptif yang melakukan deskripktif data/karakter yang kemudian dibandingkan dengan yang lain untuk mendapatkan kesimpulan

Sampel dan Wilayah Penelitian

Wilayah penelitian.

Wilayah penelitian adalah seluruh satuan lahan yang ada di Kecamatan Kamang Magek Kabupaten Agam dan dilakukan pada bulan Desember 2016, yang di tunjukkan pada peta 1 . 

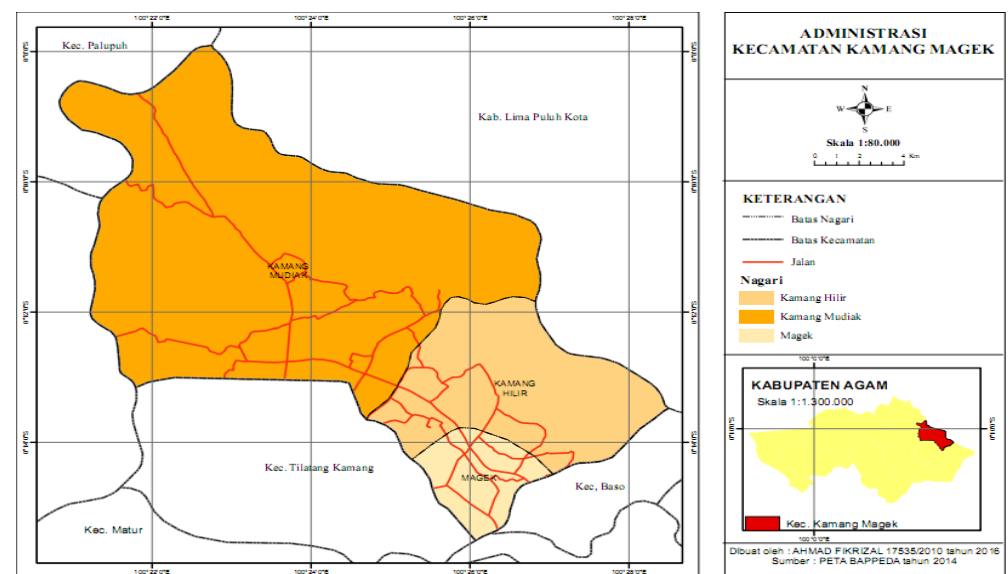

Sampel.

Sampel pada penelitian ini diambil dengan menggunakan teknik sampel wilayah (area sampling) yang didasarkan pada variasi satuan lahan. Pengambilan sampel dengan cara memilih ciri-ciri populasi yang ada (purposive sampling), dimana sampel yang diambil sebanyak satu sampel yang mewakili setiap variasi satuan lahan yang memenuhi kriteria untuk dijadikan lahan tanaman cabai.

Satuan pemetaan yang digunakan adalah satuan lahan yang diperoleh dari hasil tumpang susun peta kemiringan lereng, peta tanah, peta geologi, peta bentuklahan dan peta penggunaan lahan, dan terdapat tiga puluh lima satuan lahan pada daerah penelitian. Lebih jelasnya satuan lahan dapat dilihat pada tabel 4 dan sampel penelitian di jelaskan pada tabel 5.

Tabel 4. Satuan Lahan Daerah Penelitian.

\begin{tabular}{|c|c|c|}
\hline $\mathrm{No}$ & Satuan lahan & NoSatuan lahan \\
\hline 1 & K1 III Ht Kam & 19 K6 I Sw Kam \\
\hline & $\mathrm{Cl}$ & $\mathrm{Cs}$ \\
\hline
\end{tabular}

\begin{tabular}{|l|l|l|l|}
\hline 2 & K1 III Kc & 20 & K6 I Tg Kam \\
& Kam Cl & & Cs \\
\hline 3 & K1 III Smk & 21 & V1 I Ht Kam \\
& Kam Cl & & Qpt2 \\
\hline 4 & K1 III Sw & 22 & V1 I Kc Kam \\
& Kam Cs & & Qpt2 \\
\hline 5 & K1 IV Per & 23 & V1 I Per Kam \\
& Kam Qpt2 & & Qpt2 \\
\hline 6 & K1 IV Smk & 24 & V1 I Smk Kam \\
& Kam Qpt2 & & Qpt2 \\
\hline 7 & K1 IV Sw & 25 & V1 I Sw Kam \\
& Kam P1 & & Qpt2 \\
\hline 8 & K1 IV Sw & 26 & V1 I Tg Kam \\
& Kam Qpt2 & & Qpt2 \\
\hline 9 & K2 II Ht Kam & 27 & V2 II Ht Kam \\
& Cl & & Qpt2 \\
\hline 10 & K2 II Kc Kam & 28 & V2 II Kc Kam \\
& Cs & & Qpt2 \\
\hline 11 & K3 IV Kc & 29 & V2 II Sw Kam \\
& Kam Cs & & Qpt2 \\
\hline 12 & K3 IV Per & 30 & V4 III Ht Kam \\
& Kam Cs & & Qpt2 \\
\hline 13 & K3 IV Smk & 31 & V4 III Kc Kam \\
& Kam Cs & & Qpt2 \\
\hline 14 & K3 IV Sw & 32 & V4 III Per \\
& Kam Cs & & Kam Qpt2 \\
\hline 15 & K3 IV Tg & 33 & V4 III Smk \\
& Kam Cs & & Kam Qpt2 \\
\hline
\end{tabular}




\begin{tabular}{|c|c|c|}
\hline & $\begin{array}{l}\text { K6 I Ht Kam } \\
\text { Cs }\end{array}$ & $34 \begin{array}{l}\text { V4 III Sw } \\
\text { Kam Qpt2 }\end{array}$ \\
\hline 17 & $\begin{array}{l}\text { K6 I Kc Kam } \\
\text { Cs }\end{array}$ & $\begin{array}{ll}35 & \begin{array}{l}\text { K6 I Smk Kam } \\
\text { Cs }\end{array}\end{array}$ \\
\hline & $\begin{array}{l}\text { K6 I Per Kam } \\
\text { Cs }\end{array}$ & \\
\hline
\end{tabular}

Sumber:Hasil pengolahan data

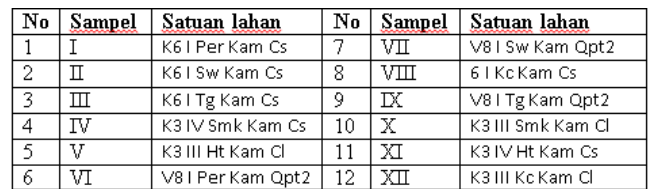

Sumber:Hasil pengolahan data.

\section{HASIL DAN PEMBAHASAN}

Berdasarkan pengukuran lapangan, peta, analisis laboratorium, dan data sekunder maka karakteristik masing-masing lahan pada setiap satuan lahan untuk tanaman cabai di Kecamatan Kamang Magek dapat diuraikan pada tabel 6 dan ditunjukkan pada peta 2 .

Tabel 5. sampel penelitian.

Tabel 6. Hasil Evaluasi Kesesuaian Lahan.

\begin{tabular}{|c|c|c|c|c|c|c|c|c|c|c|c|}
\hline \multirow[b]{2}{*}{$\mathrm{Ha}$} & \multirow[b]{2}{*}{ Satuan lahan } & \multicolumn{9}{|c|}{ Karakteristik Lahan } & \multirow[b]{2}{*}{$\begin{array}{c}\text { Kararuasian } \\
\text { lathan }\end{array}$} \\
\hline & & Drainase & $\begin{array}{c}\text { Tekstur } \\
\text { tanah }\end{array}$ & $\begin{array}{l}\text { Solum tanah } \\
\text { (cm] }\end{array}$ & $\mathrm{pH}$ tanah & Lereng $(\%)$ & Suhu [?] & $\begin{array}{l}\text { Curah hujan } \\
\text { (mmithn) }\end{array}$ & Bulan kering & $\begin{array}{c}\text { Permeabilita } \\
s\end{array}$ & \\
\hline 1 & K6 IPer Kam $\mathrm{C}=$ & 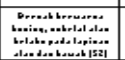 & \begin{tabular}{|l} 
Lempung list \\
berdebu [\$ $\$ 2$ ]
\end{tabular} & 52 (S4) & 6. $29(51)$ & $3(\mathrm{~s})$ & $21[S 1]$ & $1898.5(\mathrm{~S} 1)$ & $8[\mathrm{~S} 3]$ & $2,91(\mathrm{~s} 3)$ & s3 \\
\hline 2 & $\begin{array}{c}\text { VsIPer Kam } \\
\text { Qpt2 }\end{array}$ & 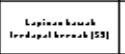 & \begin{tabular}{|l|} 
Lempung liat \\
berdebu ( $(22)$
\end{tabular} & $65[(S 3)$ & $6.07(51)$ & 5 (S1) & $21(S 1)$ & 1898,5 [S1] & $8[\mathrm{~s} 3]$ & $40,83(\mathrm{~S})]$ & s3 \\
\hline 3 & K3 III Smk Kam Cl & $\mid$ & \begin{tabular}{|l} 
Lempung list \\
berposir (S2)
\end{tabular} & $73(53)$ & $6.10[\mathrm{~S} 3]$ & $41(\mathrm{~N})$ & $21(S 1)$ & 1898.5 (S1) & $8[\mathrm{~s} 3]$ & $9.1[\mathrm{~s} 2]$ & N \\
\hline 4 & $\begin{array}{c}\text { volsw Kam } \\
\text { Qpt2 }\end{array}$ & 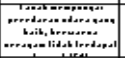 & \begin{tabular}{|l|} 
Lempung list \\
berdebu (S2)
\end{tabular} & 150 [S1] & $6.52(\mathrm{~S} 1)$ & $3(\mathrm{~S} 1)$ & $21(S 1)$ & $1898.5(\mathrm{~S} 1)$ & $8[\mathrm{~s} 3]$ & 32,08 (S1) & s2 \\
\hline 5 & $\begin{array}{c}\text { VsITg Kam } \\
\text { Qpt2 }\end{array}$ & 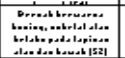 & \begin{tabular}{|l|} 
Lempung list \\
berposir (\$2)
\end{tabular} & 105 [S2] & 6. 26 (S1) & $5(S 1)$ & $21(S 1)$ & 1898.5 (s1) & $8[\mathrm{~s} 3]$ & 43.75 (S1) & s2 \\
\hline 6 & $\mathrm{~K} 61 \mathrm{~K} \subset \mathrm{K} \supset \mathrm{m} \mathrm{C} s$ & 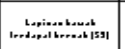 & \begin{tabular}{|l|} 
Lempung list \\
berdebu (S2)
\end{tabular} & $125[\mathrm{~S} 2]$ & 6. 25 (si) & $10[\mathrm{~S} 2]$ & $21(S 1)$ & 1898.5 (S1) & $8[\mathrm{~s} 3]$ & 81,66 (S1) & s3 \\
\hline 7 & K6 ITg Kom $\mathrm{Cr}$ & 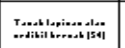 & List (\$1) & $100[\mathrm{~S} 2]$ & $5.05[\mathrm{~S} 2]$ & $3(\mathrm{~S} 1)$ & $21(S 1)$ & 1898.5 [S1] & $8(\mathrm{~s} 3)$ & $11,08[\mathrm{~S} 2]$ & s2 \\
\hline 8 & $\underset{\mathrm{C} s}{\mathrm{~K} 3 \mathrm{IV} \mathrm{Smk} \text { Kom }}$ & $\mid$ & List (si) & $65(\mathrm{~S} 3)$ & $5.70[\mathrm{~s} 2]$ & $47(\mathrm{~N})$ & $21[S 1]$ & 1898.5 (S1) & $8(\mathrm{~s} 3)$ & $2,33(\mathrm{~s} 3)$ & N \\
\hline 9 & $\mathrm{~K} 3 \mathrm{III} \mathrm{K}<\mathrm{Kam} \mathrm{Cl}$ & 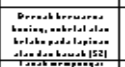 & $\begin{array}{l}\text { Lempung } \\
\text { berdebu (\$3) }\end{array}$ & 110 (s2] & $6.65(\mathrm{~S} 1)$ & $42(\mathrm{~N})$ & $21(s 1)$ & 1898.5 (S1) & $8(\mathrm{~s} 3)$ & \begin{tabular}{|c|}
$\begin{array}{c}\text { Poros (tak } \\
\text { terhinggal } \\
\text { (N) }\end{array}$ \\
\end{tabular} & $\mathrm{N}$ \\
\hline 10 & K61Sw Kom Cs & 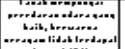 & \begin{tabular}{|c|} 
Lempung \\
berdebu (S3)
\end{tabular} & 55 (S4) & $6.75(\mathrm{~S} 1)$ & $3(\mathrm{~s} 1)$ & $21[S 1]$ & 1898.5 (S1) & $8(53)$ & 14 (S1) & s3 \\
\hline 11 & $\mathrm{~K} 3 \mathrm{III} \mathrm{Ht} \mathrm{K} ə \mathrm{~m} \mathrm{Cl}$ & $\mid$ & \begin{tabular}{|l} 
Lempung liat \\
berdebu (S2)
\end{tabular} & $45(\mathrm{~N})$ & $6.26[S 1]$ & $40(N)$ & $21[S 1]$ & 1898.5 [S1] & $8(\mathrm{~s} 3)$ & $\begin{array}{c}\begin{array}{c}\text { Poros (tak } \\
\text { terhingga) } \\
\text { [N] }\end{array} \\
\end{array}$ & $\mathrm{N}$ \\
\hline 12 & KЗ IVHe Kom Cs & 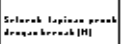 & \begin{tabular}{|l} 
Lempungliast \\
berposir (S2)
\end{tabular} & 57 [S4] & $6.5[s 1]$ & $45(N)$ & $21(S 1)$ & 1898.5 (s1) & $8(\mathrm{~s} 3)$ & $10,5[\mathrm{~S} 2]$ & $\mathrm{N}$ \\
\hline
\end{tabular}

Sumber:Hasil pengolahan data . 
Peta 2. Evaluasi Kesesuaian Lahan Kecamatan Kamang Magek.
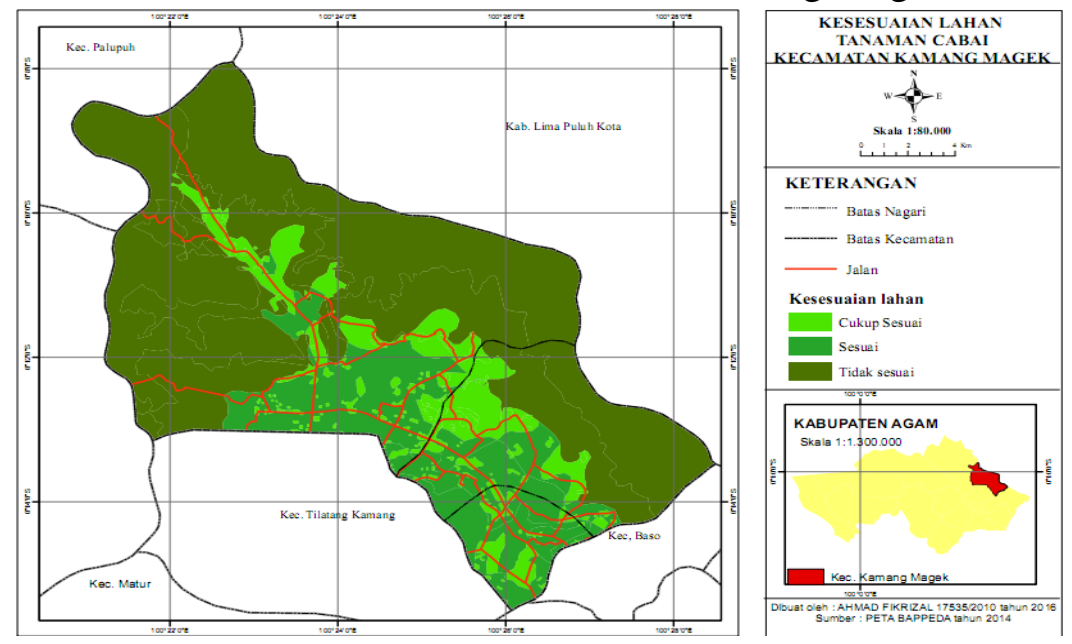

\section{a. Karakteristik Lahan Untuk} Tanaman Cabai di Kecamatan Kamang Magek

Berdasarkan hasil penelitian dengan cara pengukuran lapangan dan analisa laboratorium dan sederhana terhadap 12 (duabelas) satuan lahan, maka karakteristik lahan tanaman cabai terdapat parameter pendukung dan parameter penghambat. Diantaranya yaitu pada K6I PerKamCs berdasarkan metode matching maka faktor penghambat pada kesesuaian lahan untuk tanaman cabai adalah kedalaman solum tanah, bulan kering dan permeabilitas. Pada V8IPerKamQpt2 berdasarkan metode matching faktor penghambat pada kesesuaian lahan untuk tanaman cabai yaitu drainase, solum tanah, bulan kering. Pada K3IIISmkKamCl berdasarkan metode matching maka faktor penghambatnya adalah drainase, solum tanah, bulan kering dan lereng. V8ISwKamQpt2 faktor penghambatnya bulan kering. V8ITgKamQpt2 faktor penghambatnya adalah bulan kering. K6IKcKamCs faktor penghambatnya adalah drainase dan bulan kering. K6ITgKamCs faktor penghambatnya adalah drainase dan bulan kering. K3IVSmkKamCs faktor penghambatnya adalah drainase, solum tanah, lereng, bulan kering dan permeabilitas. K3IIIKcKamCl faktor penghambatnya adalah tekstur tanah, lereng, bulan kering, permeabilitas. K6ISwKamCs faktor penghambatnya adalah tekstur tanah, solum tanah, bulan kering. K3IIIHtKamCl faktor penghambatnya adalah drainase, solum tanah, lereng, bulan kering dan permeabilitas. K3 IV $\mathrm{Ht}$ Kam Cs factor penghambatnya adalah drainase, solum tanah, lereng dan bulan kering. 
b. Tingkat Kesesuaian Lahan Untuk Tanaman Cabai di Kecamatan Kamang Magek

Berdasarkan hasil penelitian tingkat kesesuaian lahan untuk penanaman cabai di daerah Kecamatan Kamang Magek maka diperoleh tingkat kesesuaiannya dikategorikan pada tingkat kesesuaian.

a) Sesuai (S2), terdiri dari satuan lahan V8 I Sw Kam Qpt2, V8 I Tg Kam Qpt2, K6 I Tg Kam Cs.

b) Cukup sesuai (S3), terdiri dari satuan lahan K6 I Per Kam Cs, V8 I Per Kam Qpt2, K6 I Kc Kam Cs, K6 I Sw Kam Cs.

c) Tidak sesuai $(\mathrm{N})$, terdiri dari satuan lahan K3 III Smk Kam Cl, K3 IV Smk Kam Cs, K3 III Kc $\mathrm{Kam} \mathrm{Cl,} \mathrm{K3} \mathrm{III} \mathrm{Ht} \mathrm{Kam} \mathrm{Cl,} \mathrm{K3} \mathrm{IV}$ Ht Kam Cs.

\section{PENUTUP}

\section{Kesimpulan}

Berdasarkan hasil penelitian dan pembahasan pada bab sebelumnya maka dapat dikemukakan kesimpulan sebagai berikut ini

karakteristik lahan pada daerah penelitian dapat dilihat secara keseluruhan pada tabel 5.13 dengan beberapa faktor penghambat yaitu kedalaman solum tanah, drainase, lereng, permeabilitas.

Tingkat kesesuaian lahan untuk areal penanaman cabai di Kecamatan Kamang Magek terbagi atas tiga tingkatan yaitu sesuai (S2), cukup sesuai (S3) dan tidak sesuai (N)

\section{Saran}

Berdasarkan faktor-faktor penghambat yang terdapat di daerah penelitian, hendaknya para petani dapat melakukan pemilihan untuk lahan tanaman cabai ini sebelum penanaman cabai agar hasil cabai maksimal.

Agar dinas yang terkait, dalam ini dinas pertanian lebih memperhatikan tentang pentingnya arti kesesuaian lahan ini, tidak hanya untuk tanaman cabai tapi untuk tanaman lain.

\section{E DAFTAR PUSTAKA}

Asdak, Chay. 1995. Hidrologi dan Pengelolaan Daerah Aliran Sungai. Yogyakarta: Gajah Mada University Press

BPS. 2013. Sumatera Barat dalam angka. BPS Sumatera Barat

BPS.2013. Survei Pertanian Kabupaten Agam dalam angka. BPS Sumatera Barat

BPS.2013. Kecamatan Kamang Magek dalam angka. BPS Sumatera Barat

BPS.2015. Kecamatan Kamang Magek dalam angka. BPS Sumatera Barat

Hardjowigeno, Sarwono. 2007. Ilmu Tanah. Jakarta: Akademika Pressindo

Hardjowigeno, Sarwono dan Widiatmaka. 2011. Evaluasi Kesesuaian Lahan dan Perencanaan Tataguna 
Lahan. Yogyakarta: Gadjah Mada University Press

Hermon, Dedi dan Khairani. 2009. Geografi Tanah Suatu Tinjauan Teoritis, Metodologis, dan Aplikasi Proposal Penelitian. Padang. Yayasan Jihadul Khair Center

Ritung, S, Wahyunto, Agus,F, dan Hidayat, H. 2007.Evaluasi Kesesuaian Lahan. Balai Penelitian Tanah dan World Agroforestry Center.Bogor (www.Evaluasi Kesesuaian Lahan.com)

Statistik Produksi Holtikultura tahun 2014. 2015: Direktorat Jenderal Holtikultura Kementerian Pertanian

Sumarni, Nani dan Agus Muharam. 2005. Budidaya Tanaman Cabai Merah. Bandung: Balai Penelitian Tanaman Sayuran

Dibyosaputro, Suprapto. 1998.

Catatan Kuliah Gemorfologi Dasar. Yogyakarta: Departemen Pendidikan dan Kebudayaan Universitas Gadjah Mada Fakultas Geografi 